\title{
ПРОФЕСІЙНА ОСВІТА
}

\author{
УДК [378.091.212:373.3]:17.022.1 \\ DOI 10.31494/2412-9208-2019-1-1-225-233
Contemporary trends in the training of future teachers for the moral education of elementary school students

\section{Сучасні тенденції підготовки майбутніх учителів до морального виховання учнів початкової школи}

\author{
Iryna Batareina, \\ postgraduate student \\ irinabatpryanichnikova@gmail.com \\ Ірина Батарейна, \\ аспірантка \\ Melitopol B. Khmelnytsky State \\ Мелітопольський державний \\ Pedagogical University \\ педагогічний університет \\ 20 Getmanska St., \\ імені Б.Хмельницького \\ $\triangle$ вул. Гетьманська, 20 \\ Melitopol, Zaporizhzhiaye region, \\ 72300 \\ м. Мелітополь, Запорізька обл., \\ 72300 \\ Original manuscript received January 17, 2019 \\ Revised manuscript accepted April 24, 2019
}

\begin{abstract}
Reforming the education system in Ukraine provides for greater freedom for teachers. The new Ukrainian school needs a teacher of creative, initiative, democratic, capable of organizing an educational process based on partnership pedagogy, mastering new pedagogical and information technologies. In addition, the teacher of the New Ukrainian school has to implement a personally oriented model of education, based on the ideology of child-centeredness, that is, the maximum approximation of education and education of a particular child to its essence, abilities and life plans.

The formation of these qualities to a large extent depends on the readiness of the teacher to self-improvement and self-education. The present era is characterized by processes of formation of a new paradigm in the philosophy and theory of education. New world perceptions and attitudes create a change in the educational view of the development and formation of the child's personality, determine the opportunities, tasks, goals and means of education. The construction of a new educational model involves theoretical rethinking and practical orientation towards a new ideal. It is possible to produce highly qualified specialists only subject to strict adherence to and compliance with the state standards of education and normative documents of the Ministry of Education and Science of Ukraine, as well as the technological regime for constructing the educational process at all stages of the life cycle - from admission of students to an educational institution and before their release. Today's requirements dictate the need for constant updating of the content of education, the development of new educational and methodological complexes, the search for new innovative technologies as learning, and the control of the success of the educational process for the qualitative training of future teachers for the moral education of elementary school students. Teacher training for a modern elementary school is one of the topical issues of higher education in Ukraine. The formation of an updated educational system in Ukraine takes place in
\end{abstract}


Серія: Педагогічні науки. - Вип.1. - Бердянськ : БДПУ, 2019. - 406 с.

conditions of accelerating global integration into the world community under the influence of an ethnic factor to preserve the integrity of national statehood and restore the spiritual priorities of society.

Key words: upbringing, moral upbringing, New Ukrainian school, moral qualities, moral upbringing, teacher training.

Вступ. Становлення і розвиток Української держави підвищують роль духовних та моральних засад, які визначають поведінку людини, сприяють утвердженню її активної життєвої позиції. У цьому контексті моральному вихованню належить провідна роль. Проблеми морального виховання молоді порушено в низці нормативно-правових документів: Національній доктрині розвитку освіти України у XXI ст. (2002), законах України “Про освіту" (2017), “Про вищу освіту" (2014), Концепції національного виховання студентської молоді (2009), Концептуальних засадах розвитку педагогічної освіти України та її інтеграції в європейський освітній простір (2004), Національній стратегії розвитку освіти України на період до 2021 року (2012), Галузевій концепції розвитку неперервної педагогічної освіти (2013), Концепції Нової української школи (2016) та ін.

Мета статті - висвітлити сучасні тенденції підготовки майбутніх учителів до морального виховання учнів початкової школи.

Методи та методики дослідження. У статті було використано такі методи дослідження: теоретико-методологічний аналіз, синтез, узагальнення для вивчення філософської і наукової літератури з проблем дослідження; системно-структурний (класифікація, систематизація); порівняльний - (визначення загальних та особливих закономірностей).

Результати та дискусії. Зміст морального виховання включає в себе формування національної свідомості, виховання любові до розбудови національної державності; патріотизм; участь молоді в практичних справах розбудови нашої держави; формування в учнів почуття гідності, гордості за свою Батьківщину, вірності Україні. Моральні цінності поділяються на такі групи: загальнолюдські, абсолютно вічні, які мають необмежену сферу застосування (гуманізм, доброта, чесність, правда, гідність, мудрість, справедливість, відчуття прекрасного тощо); національні - значущі для одного народу (патріотизм, почуття національної гідності, історична пам'ять тощо); громадянські - це визнання прав і свобод людини, обов'язку перед іншими людьми, поваги до закону, державних символів, уряду, до ідеї соціальної гармонії тощо; сімейні - моральні основи життя сім'ї, стосунки поколінь, закони подружньої вірності, піклування про дітей, старших, пам'ять про предків, взаємоповага в сім'ї; цінності особистого життя - девіз, за яким живе людина, орієнтири поведінки, цілі, прагнення. Вони визначають риси їі характеру, поведінку, успіхи, стиль особистого життя. Моральне виховання - це виховний вплив школи, сім'ї, громадськості, що має на меті формування стійких моральних якостей, потреб, почуттів, навичок поведінки на основі засвоєння ідеалів, норм і принципів моралі та практичної діяльності. Мораль - це система принципів, норм і правил, які регулюють поведінку людини в суспільстві, роблять її правильною. 
Поняття "моральний", "моральність" використовують, коли йдеться про конкретний вчинок, практичну сторону стосунків. Отже, мораль, етику і моральність не можна вважати синонімами (Волкова, 2007).

Поведінку людини оцінюють за ступенем відповідності певним правилам. Ці правила дозволяють оцінити вчинок і прийти до єдиної думки: добре чи погано вчинила людина. Правило, що має загальний характер, тобто поширюється на однакові вчинки, називають моральною нормою. Норма визначає, як людина повинна чинити в тій чи іншій конкретній ситуації. Залежно від сфер відносин між людьми (професійна, сімейна, міжнародна та інші) норми об'єднуються в групи і регулюються вихідним началом тієї чи іншої сфери - моральними принципами. Поняття моралі, що мають загальний характер, тобто охоплюють не окремі відношення, а всі сфрери взаємин, спонукають людину скрізь і всюди керуватись ними, мають назву моральні категорії. Суспільство виробляє зразок моральної поведінки - моральний ідеал, до якого повинні прагнути всі, вважаючи його розумним, красивим, корисним. Моральна культура учнів - це засвоєння особистістю моральних норм, принципів, категорій, ідеалів суспільства на рівні власних переконань, дотримання їх як звичних норм особистої поведінки. Змістом виховної роботи вчителя, класного керівника по становленню моральної культури учнів $€$ формування в них системи моральних знань, почуттів, ставлень, поведінки.

Моральний розвиток учнів проходить три стадії (Л. Кольберг). На доморальному рівні дитина виконує вимоги, боячись покарання. На конвенційному рівні дотримання моралі визначається намаганням належати групі, суспільству, відповідати їх вимогам з метою самозбереження. Третій рівень морального розвитку автономний: людина добровільно обирає моральну поведінку, бо переконана, що жити їй потрібно згідно з нормами, прийнятими нею добровільно. Зміст морального виховання учнів передбачає утвердження принципів загальнолюдської моралі - правди, справедливості, патріотизму, доброти, працелюбності та інших доброчинностей на національному ґрунті (Луцик, 2007).

Виховання моральної культури школярів здійснюється у різноманітних видах діяльності: навчальній, трудовій, громадсько-корисній, особливо таких видах, де учні поставлені в ситуації безпосереднього вияву турботи про інших, надання допомоги і підтримки, захисту слабшого, молодшого, хворого і под. До форм морального виховання відносять спеціальні уроки, етичні бесіди, відверті розмови, диспути, лекції, тематичні вечори, зустрічі свят народного календаря, благодійні заходи, створення альманахів з історії родоводу, вечорниці та інші.

Основними методами і способами морального виховання дітей і молоді К. Ушинський вважав переконання, запобігання неправильній поведінці, педагогічний такт учителя та заохочення і покарання, але не тілесні; особистий приклад учителя, а також батьків і старших, правильний режим, навчання тощо. Але найкращим засобом морального виховання, на його думку, $\epsilon$ фізична праця, за допомогою якої формуються кращі моральні якості дітей і молоді, але з умовою 
правильного поєднання її з працею розумовою.

Я. Корчак стверджував, що "рефрорми в житті дорослих слід починати в душах дітей" (Волкова, 2007). Саме молодший шкільний вік $\epsilon$ сенситивним для морального розвитку особистості, її психічних пізнавальних процесів, емоційно-почуттєвої та мотиваційно-ціннісної сфер. Різні аспекти морального виховання особистості були темою досліджень багатьох філософрів, педагогів, психологів різних епох та країн, а саме: М. Бердяєва, П. Блонського, В. Гегеля, Г. Гельвеція, І. Гербарта, О. Духновича, І. Канта, П. Каптерева, Я. Коменського, А. Макаренка, Г. Сковороди, В. Сухомлинського, К. Ушинського. Структуру морального виховання та формування в підростаючого покоління загальнолюдської моралі вивчали І. Бех, Н. Волкова, Г. Іванова, М. Красовицький, О. Матвієнко, В. Мацулевич, В. Руденко, О. Скрипченко, М. Фіцула, К. Чорна, Л. Шульга, П. Щербань.
Л. Толстой,
А. Макаренко,
В. Сухомлинський,
Н. Болдирєв, І. Харламов, І. Мар'єнко, Б. Лихачов, Л. Попов, Л. Григорович, І. Підласий висвітлюють у своїх працях сутність основних понять теорії морального виховання, змісту, методів морального виховання. Мораль історично конкретна, вона змінюється з розвитком суспільства. Л. Григорович дав таке визначення моральності - як особистісної характеристики, що об'єднує такі якості і властивості, як доброта, порядність, дисциплінованість, колективізм. Моральність - невід'ємна складова особистості, що забезпечує добровільне дотримання нею існуючих норм, правил, принципів поведінки. Моральні норми - це правила, вимоги, що визначають, як людина повинна діяти в тій чи іншій конкретній ситуації. Виховання - процес цілеспрямованого формування особистості. Моральне виховання - це цілеспрямований і систематичний вплив на свідомість, почуття і поведінку учнів 3 метою формування в них моральних якостей, які відповідають вимогам суспільної моралі. Моральне виховання учнів - складний і багатогранний процес, що включа педагогічні та соціальні явища. Однак процес морального виховання певною мірою автономний. На цю його специфріку свого часу вказував А. Макаренко. Основні завдання морального виховання: формування моральної свідомості; виховання і розвиток моральних почуттів; вироблення умінь і звичок моральної поведінки. Моральна свідомість активний процес відображення моральних відносин, станів. Суб'єктивною рушійною силою розвитку моральної свідомості $є$ моральне мислення процес постійного накопичення і осмислення моральних фрактів, відносин, ситуацій, їх аналіз, оцінка, прийняття етичних рішень, здійснення відповідальних виборів. Найважливішим засобом морального виховання $€$ використання створених в культурі на різних етапах історичного розвитку моральних ідеалів, тобто зразків моральної поведінки, до якого прагне людина.

Л. Григорович розглядав зміст морального виховання через гуманність. Гуманність - це інтегральна характеристика особистості, включає комплекс її властивостей, що виражають ставлення людини до 
людини. Крім гуманності у зміст морального виховання входить виховання свідомої дисципліни і культури поведінки. Моральна вихованість - це стійкість позитивних звичок і звичних норм поведінки, культура стосунків і спілкування в умовах здорового дитячого колективу (Григорович, 2001).

О. Кисельова надає таке визначення моральному вихованню - це засвоєння підростаючим поколінням моральних цінностей, норм, принципів, правил, звичок, традицій, що в сукупності становлять моральну культуру суспільства в якому живуть діти. Н. Шагай у своєму дослідженні доводить, що зміст морального виховання передбачає утвердження принципів загальнолюдської моралі - правди, справедливості, патріотизму, доброти, працелюбності та інших доброчинностей на національному ґрунті, він зумовлений потребами і вимогами суспільства до формування всебічно розвиненої особистості, рівнем його моральності.

У словнику В. Даля мораль трактується як "правила для волі та совісті". Моральність - це етичне поняття, яке в широкому розумінні $€$ синонімом моралі. Структура моралі складається з моральної свідомості, моральної діяльності та моральних відносин. У науковій літературі моральна свідомість розглядається як один з елементів моралі, форма суспільної свідомості і одночасно сфера індивідуальної свідомості особи, оскільки це своєрідний сплав почуттів, уявлень, оцінок і самооцінок, поглядів і переконань людини.

Так, моральні знання $€$ початковою сходинкою в процесі опанування учнями моральних переконань та цінностей. О. Матвієнко, досліджуючи виховання моралі в молодших школярів, стверджує, що моральні знання - це той об'єм етичних понять, які $€$ доступні і відповідають віковим особливостям дитини. Педагог підкреслювала, що моральні знання - це передусім знання добра. 3 позиції фрілософії Гегель визначав добро як: "абсолютну мету світу і обов'язок для суб'єкта, який повинен мати розуміння добра, зробити його своїм наміром і здійснювати в своїй діяльності". Спираючись на це твердження, О. Матвієнко виокремила програму моральних взаємин особистості: зрозуміти, пізнати, зробити своїм наміром - пережити, виробити переконання, визначити мотиви і, нарешті, реалізувати добро в поведінці та стосунках. С. Рубінштейн зазначав, що "моральні почуття сягають своїм корінням у суспільне буття людей". В. Зенківським були виділені три провідні неперехідні моральні почуття: любов до людей, сором та "почуття совісті". Н. Шагай виокремила найбільш вагомі для молодших школярів три групи моральних якостей. До першої групи відносяться властивості суб'єктивної моралі, які відповідають категоріям блага, добра, зла, справедливості. Другу групу якостей суб'єктивної моралі школяра складають ті, що пов'язані з категоріями смислу життя і щастя. Гідність, обов'язок, відповідальність, честь і совість належать до третьої групи моральних якостей. І. Бех зазначає, що процес формування моральної свідомості в молодшого школяра буде особливо складним і суперечливим 
за наявності розбіжностей між поглядами сім'ї та школи. Ось чому він радить ураховувати ці моменти при налагодженні контактів між школою і сім'єю, інакше невпевненість вибору між оцінкою школи та сім'ї може сприяти формуванню конфрормістських якостей, соціальної безвідповідальності у дітей (Чорна, 2008).

С. Карпенчук розглядає вихованість як властивість особистості, яка характеризується "сукупністю достатньо сформованих соціально значущих якостей, які відбивають в узагальненій фрормі систему ставлень людини до суспільства і колективу, розумової та фізичної праці, до людей, до себе".

Методи морального виховання - це своєрідний інструмент в руках вчителя. Вони виконують функції організації процесу морального розвитку та вдосконалення учнів. За допомогою методів морального виховання здійснюється цілеспрямований вплив на учнів, організується і направляється їх життєдіяльність, збагачується їхній моральний досвід. Форми організації та методи морального виховання змінюються від індивідуальних особливостей дітей. Виховна робота проводиться не тільки з усім класом, але і приймає індивідуальні фооми. І. Мар'єнко назвав такі групи методів виховання, як методи привчання і вправи, стимулювання, гальмування, самовиховання, керівництва, пояснювально - репродуктивні та проблемно-ситуативні. У процесі морального виховання широко застосовуються такі методи як: вправу і переконання. Вправа - забезпечує вироблення і закріплення необхідних навичок та звичок, втілення навичок і звичок на практиці. Переконання - направлено на формування етичних понять, на роз'яснення моральних принципів, на вироблення етичних ідеалів. Для активізації морального розвитку особистості та перевірки її зрілості, встановлення єдності переконань і поведінки використовується метод проблемно-ситуаційний. Самостійне рішення моральних проблем, в різних життєвих ситуаціях дозволяє встановлювати зв'язок між вчинками і якостями учнів, фоорувати позитивні мотиви, узагальнювати моральні знання та вміння. Цей метод включає такі прийоми: постановку моральних завдань, створення колізій і ситуацій, завдання на самостійне продовження і закінчення моральної завдання з вирішення початку. У процесі морального виховання застосовуються і такі допоміжні методи як заохочення і покарання. Вони служать для схвалення позитивного і судження негативних вчинків і дій. До методів морального виховання ставиться так само особистий приклад, який має великий вплив на свідомість і поведінку, на формування морального обличчя. У системі основних методів виховного впливу як складова частина, засіб і прийом використовується позитивний приклад. Моральне виховання ефективно тоді, коли його наслідком стає моральне самовиховання і самовдосконалення (Вишневський, 1996).

Ефективність морального виховання учнів визначають такі чинники: створення у закладі освіти психологічного клімату поваги до моральних норм, правил людського співіснування; відповідність змісту морального виховання його меті й рівню морального розвитку вихованців; розумне співвідношення між словесними і практичними методами 
виховного впливу, що забезпечує єдність моральної свідомості і поведінки; своєчасне вживання виховних заходів, акцентування уваги на попередженні аморальних явищ в учнівському колективі; подолання авторитарного стилю у ставленні педагогів до вихованців, побудова його на принципах гуманізму. У процесі морального виховання важливо попередити прояви і розвиток таких рис і якостей особистості, які можуть призвести до порушення моральних норм. Тому завдання вчителя формувати в учнів тверду моральну позицію, здатність протистояти негативним впливам з боку близького оточення і соціуму загалом.

Висновки. Таким чином, проблема вивчення морального виховання $\epsilon$ актуальною. Подальшої розробки потребують питання вивчення тенденцій розвитку морального виховання. В Україні останніми роками проблема морального виховання учнів привертає все більше уваги. Адже вирішення даної проблеми має забезпечити високий розвиток особистості незалежно від того, в якій галузі їй доведеться працювати. Система моральних цінностей в українців сформувалася здавна. Пошук шляхів до цілісного, гармонійного світу та людського буття не може не зачіпати проблем освіти й виховання. Сьогодні не тільки педагогічні, а й глобальні проблеми (демографічні, економічні кризи, криза урбанізації, екологічні катастрофи, загострення міжнаціональних суперечностей і конфліктів, криза культури та моралі тощо) зумовлюють відродження гуманістичних ідей у суспільстві. Теперішня епоха характеризується процесами становлення нової парадигми у філософії та теорії освіти. Нове світосприйняття та світовідчуття спричиняють зміну в освітніх поглядах на розвиток і формування особистості дитини, визначають можливості, завдання, мету й засоби освіти. Побудова нової освітньої моделі передбачає теоретичне переосмислення та практичну орієнтацію на новий ідеал. Особливо важливо це враховувати в педагогічній діяльності у різних сферах життєдіяльності школярів: в школі, позанавчальних соціально-виховних закладах, в об'єднаннях чи клубах за інтересами тощо.

На основі викладеного матеріалу ми можемо стверджувати, що моральне виховання молодших школярів інтегрується в освітній процес, під час якого учень озброюється знаннями моральних норм і правил, вивчає моральні цінності та почуття, що $є$ передумовою формування мотивів моральної поведінки. Чим вищий рівень моральної культури діючого середовища формування особистості, тим підвищується ступінь вірогідності залученості дитини молодшого шкільного віку до ідей гуманізму та зростання її моральної культури. Подальшого розроблення потребують сучасні соціально-педагогічні умови ефективності морального виховання молодших школярів у початковій школі, а також удосконалення форм і методів педагогічної діяльності.

Пріоритетного значення в розбудові нової школи набуває завдання формувати в учнів систему загальнолюдських цінностей - моральноетичних (гідність, чесність, справедливість, турбота, повага до життя, повага до себе та інших людей) та соціально-політичних (свобода, 
демократія, культурне різноманіття, повага до рідної мови і культури, патріотизм, шанобливе ставлення до довкілля, повага до закону, солідарність, відповідальність). У центрі освіти має перебувати виховання в учнів відповідальності за себе, за добробут нашої країни.

\section{Література}

1.Вишневський О. Сучасне українське виховання: Педагогічні нариси / Вишневський О. - Львів : Львівський обл. науково-методичний інститут освіти; Львів, обл. пед. Т-во ім. Ващенка, 1996. - 238 с.

2.Волкова Н. Педагогіка. 2-ге видання, перероблене, доповнене / Волкова Н. П. - К. : Академвидав. - 2007. - 616 с.

3.Григорович Л. А. Педагогіка і психологія. - Москва, 2001 р. - 480 с.

4.Закон України “Про освіту” від 05.09.2017 № 2145 - V I I I ст. 1-7. URL: http://zakon.rada.gov/lavs/show/2145-19 (дата звернення: 05.01.2019).

5. Закон України “Про загальну середню освіту” від 13. 05. 1999. № 651 - X I ҒV cт. 1-2. URL: http://zakon.rada.gov/lavs/show/651-14 (дата звернення: 05.01.2019).

6. Концепція "Нова українська школа" Схвалено рішенням кол. МОН України від 27.10.2016. URL:https://mon.gov.ua/ua/tag/nova-ukrainska-shkola (дата звернення 05.01.2019).

7.Луцик Д. В. Педагогіка. Теорія національного виховання: [Навчальний посібник] / Луцик Д. В.- Дрогобич: Посвіт, 2007. - 143 с.

8. Нова українська школа : порадник для вчителя / Під. Заг. Ред. Н. М. Ібік. К.: ТОВ “Видавничий дім “Плеяди”, 2017. 206 с.

9.Проект Концепції розвитку освіти України на період 2015-2025 років [Електрон. ресурс]. - 2015. - Режим доступу : http://osvita.ua/news/43501/

10. Чорна К. І. Моральне виховання / Енциклопедія освіти // Акад. пед. наук України; головний ред. В. Г. Кремень. - К.: Юрінком Інтер, 2008. - С. 523 - 524.

\section{References}

1.Vyshnevskiy, O. (1996). Suchasne ukrainske vyhovannya [Contemporary Ukrainian Education].Lviv: obl.ped.t-vo im. Vashenka [in Ukrainian].

2. Volkova N. (2007) Pedagogika [Pedagogy]. Kyiv: Akademvydav [in Ukrainian].

3.Grygorovych L. A. (2001) Pedagogika i psyhologiya [Pedagogy and psychology]. Moskva [in Russian].

4.Zakon Ukrainy "Pro osvitu" vid 05. 09. 2017 № 2145 - VIII st. [The Law of Ukraine "On Education" dated September 5, 2017 № 2145] (2017, September 5) URL: http://zakon.rada.gov/lavs/show/2145-19 [in Ukrainian].

5.Zakon Ukrainy "Pro zagalnu serednyu osvitu" vid 13. 05. 1999. № 651 - XIV st. [The Law of Ukraine "On General Secondary Education" dated 13.05.1999. № 651] (1999, May 13) URL: http://zakon.rada.gov/lavs/show/651-14 [in Ukrainian].

6. Koncepciya "Nova ukrainska shkola" vid 27. 10. 2016 [Concept "New Ukrainian School" Approved by decision count. Ministry of Education and Science of Ukraine dated 27.10.2016] (2016, Oktober 27) URL: https: //mon.gov.ua/en/tag/novaukrainska-shkola [in Ukrainian].

7.Lutsik D. V. (2007) Pedagogika. Teoriya natsionalnogo vyhovannya [Pedagogy. The theory of national education]. Drogobych: Posvit [in Ukrainian].

8. Ibik N. M. (2017) Nova ukrainska shkola. [New Ukrainian School]. Kyiv: TOV "Vydavnychyi dim "Pleyady" [in Ukrainian].

9.Proekt Kontseptsii pozvytku osvity Ukrainy na period 2015-2025 rokiv. [Draft Concept for the Development of Ukrainian Education for the period 2015-2025] (2015) URL: http://osvita.ua/news/43501/ [in Ukrainian]. 
10. Chorna K. I. (2008) Moralne vyhovannya [Moral upbringing]. Kyiv: Yurinkom Inter [in Ukrainian].

\section{АНОТАЦІЯ}

Реформуванням системи освіти в Україні передбачено надання більшої свободи вчителям. Нова українська школа потребує вчителя творчого, ініціативного, демократичного, здатного до організації освітнього процесу на основі педагогіки партнерства, оволодіння новими педагогічними та інфрормаційними технологіями. Крім того, вчитель Нової української школи має реалізувати особистісно зорієнтовану модель освіти, засновану на ідеологіі дитиноцентризму, тобто максимального наближення навчання $i$ виховання конкретної дитини до її сутності, здібностей і життєвих планів.

Формування цих якостей значною мірою залежить від готовності вчителя до самовдосконалення та самовиховання. Теперішня епоха характеризується процесами становлення нової парадигми у фрілософрії та теорії освіти. Нове світосприйняття та світовідчуття спричиняють зміну в освітніх поглядах на розвиток і формування особистості дитини, визначають можливості, завдання, мету й засоби освіти. Побудова нової освітньої моделі передбачає теоретичне переосмислення та практичну орієнтацію на новий ідеал. Випускати висококваліфрікованих фахівців можна тільки за умов суворого дотримання й виконання державних стандартів освіти та нормативних документів Міністерства освіти і науки України, а також технологічного режиму побудови освітнього процесу на всіх етапах життєвого циклу - від прийому студентів до закладу вищої освіти, до їхнього випуску. Вимоги сьогодення диктують необхідність у постійному оновленні змісту освіти, у розробленні нових навчально-методичних комплексів, пошуку нових інноваційних технологій як навчання, так і контролю за успішністю освітнього процесу для якісної підготовки майбутніх учителів до морального виховання учнів початкової школи. Підготовка вчителів сучасної початкової школи є однією з актуальних проблем вищої освіти в Україні. Становлення оновленої освітньої системи в Україні відбувається в умовах прискорення глобальної інтеграції до світового товариства під впливом етнічного чинника на збереження цілісності національної державності та відновлення духовних пріоритетів суспільства.

Ключові слова: виховання, моральне виховання, Нова українська школа, моральні якості, моральна вихованість, підготовка учителів. 